\title{
DOI 10.26886/2414-634X.4(23)2018.14
}

UDC 303.732.4

\section{MODERN CULTURE AND VIRTUAL REALITY: DIALECTICS OF INTERACTION}

\section{Chikarkova, Doctor of Philosophy, Professor}

Yuriy Fedkovych Chernivtsi National University, Ukraine, Chernivtsi

The article investigates the problem of virtual reality in contemporary culture at the level of its various aspects (education, science, politics, religion, art). According to the author, virtuality can not be linked exclusively to the "computer format", since it has long functioned in such spheres of culture as religion with its transcendental dimension, political and legal ideals, scientific abstractions, the artistic world of literature and art, etc. Online technologies that facilitate the construction of virtual reality, open up new horizons to modern culture, but at the same time they give rise to new problems.

Key words: modern culture, virtual reality, identity, virtualization, online technologies, morality.

доктор фрілософрських наук, профресор М. Ю. Чікарькова Сучасна культура і віртуальна реальність: діалектика взаємовпливу/ Чернівецький національний університет імені Юрія Федьковича, Україна, Чернівці

У статті досліджується проблема віртуальної реальності в сучасній культурі на рівні різних їі аспектів (освіта, наука, політика, релігія, мистецтво). На думку автора, віртуальність не можна пов'язувати виключно з «комп'ютерним форматом», оскільки вона віддавна фрункціонує в таких сфрерах культури, як релігія з ї трансцендентальним виміром, політичні та правові ідеали, наукові абстракції, художній світ літератури та мистецтва тощо. Онлайн- 
технології, які полегшують побудову віртуальної реальності, відкривають перед сучасною культурою нові обрії, але водночас породжують і нові проблеми.

Ключові слова: сучасна культура, віртуальна реальність, ідентичність, віртуалізація, онлайнові технології, мораль.

Вступ. Термін «віртуальна реальність» знайомий усім, і сьогодні нам вже важко уявити собі світ без Інтернету, імерсивності комп'ютерних ігор, корисних додатків на смартфоні тощо. Утім, сучасна масова ментальність потрактовує віртуальну реальність спрощено й модернізовано, як один з аспектів цифрових технологій. Нині ми звично пов'язуємо її з технічними (комп'ютерними) засобами, уживаючи також синоніми штучна реальність, електронна реальність, комп'ютерна модель реальності. Проте зазначимо, що це поняття обіймає собою набагато більше, аніж технічні можливості комп'ютерних технологій. Так, фрілософський словник подає наступне визначення терміну: «віртуальна реальність <..> - нематеріальне буття об'єктивних сутностей або суб'єктивних образів, що протиставляється матеріальному буттю речей та явищ у просторі та часі», вона «приблизно співпадає за значенням з поняттям ідеальної реальності» і може трактуватися як «можливість, що штучно реалізується» [1]. Отож віртуальна реальність може виступати одним з шляхів моделювання «можливих світів». У людини завжди була ірраціональна потреба у спілкуванні з тим, що «не існує». І хоча термін «віртуальна реальність» 1 був введений наприкінці 80-х рp. XX ст. Дж. Ланьє, але, по суті, він фрормувався у середньовічній схоластиці, яка прагнула переосмислити Платона й Аристотеля шляхом введення категорій virtus (потенціний або уявний; також енергія, сила) та realis - речовий,

1 Він є спадкоємцем введеного М. Крюгером раніше (у 60-ті рр.) терміну итучна реальність. 
дійсний, існуючий). І не можна заперечувати, що історико-культурний досвід людства побудований не на самій лише «фрізиці», але й «метафрізиці» (у класичному сенсі слова). Світ ідей Платона, Абсолютна ідея Гегеля, Царство Небесне у християнстві, «Дао» Лаоцзи, нірвана індуїстів чи буддистів тощо - усе це прояви віртуальної реальності. Навіть вульгарна наркоманія чи пияцтво теж $є$ врешті-решт пошуком трансу й виходу з реальності [2]. Поняття віртуальної реальності невіддільне від поняття культури, а без останньої людина не може іменуватися людиною. Отже, нам видається цілком слушною гіпотеза В. Корабльової щодо віртуальної креативності людини як її суттєвої антропологічної характеристики, а історії людства - як історії віртуалізації [3, сс. 31, 33]. Інша справа, що протягом історії людства віртуальність також розвивалася, модифрікуючись.

Сьогоднішній рівень розвитку науки й техніки пропонує модерні шляхи виходу за межі реальності, пов'язані з розвитком віртуалістики. «Можливо, найбільше значення для сучасної людини, що втратила віру в Бога та інші (особливо духовні) світи, окрім земного, мають відкриті комп'ютерними технологіями нові можливості задоволення важливішої потреби людського духу, пов'язаної з проривом за межі реального, в область інакшого, зокрема віртуального» [4]. Для сучасної людини віртуальна реальність стала надзвичайно актуальним поняттям, а непоодинокі випадки (іноді - з смертельним виходом), пов'язані 3 «відпадінням» у світ комп'ютерних ігор, свідчать про те, що віртуальна реальність може дуже часто ставати більш «реальною», ніж наша звична матеріальна. Громадяни СРСР, яким була примусово нав'язана секулярна релігія комунізму, не помічали, що марнують один раз дане їм життя, віддаючи його майже до останку на побудову химери. I цими прикладами ситуація, як очевидно, не вичерпується. Усе це обумовлює актуальність дослідження. 
Ступінь вивченості проблеми. Питання про вплив віртуальної реальності на сучасну культуру приваблює дослідників спорадично, хоча нині вже існує навіть термін «віртуальна культура». У дисертації Д. Усанової зроблена спроба охарактеризувати взаємодію віртуальної реальності та культури, й тут, зокрема, зазначається, що віртуальна реальність «являє собою ідеальний вектор існування культури у цілому: це все те, що мислимо та представимо у будь-якій соціокультурній системі, але не має предметного виразу» [5, с. 19]. Але, відзначаючи ґрунтовність праці та ерудованість автора, зазначимо, що у центрі уваги дослідника знаходяться насамперед теоретичні питання фрункціонування та формування віртуальної культури і дві субкультури (толкієністів та кібермандрівників), а не цілісний френомен культури. У ґрунтовній монографрії Е. Кіна проголошується епатажна теза про смерть культури завдяки Інтернету. На основі численних прикладів і статистичних викладок автор доводить тезу, що технології стали просто «великим звабленням» демократизація призвела до приниження досвіду і таланту, обіцянки дати більш повну та об'єктивнішу інформацію - до комунікативного шуму десятків тисяч блоггерів, а «цифровий паноптикум» дав можливість шпигувати одне за одним, забувши про норми моралі [6, pp. 15-16, 177]. Звертаючись до теми віртуальної реальності (віртуальної культури), науковці зазвичай зосереджуються лише на сфрері сучасного мистецтва, зате тут вже існують доволі ґрунтовні наукові дослідження шанованих авторитетів у сфері культурології [7, с. 50-90]. П. Браславський пов'язує з віртуальною реальністю, яку називає одним із фракторів трансформаційних процесів сучасної культури, зміни у масовій свідомості та естетичному досвіді, але приділяє увагу лише театру та кіно [8, с. 88-123], Ю. Насєдкіна вивчає перетин віртуальної реальності та художньої культури [9, с. 104-140]. 
Активно досліджується вплив на формування віртуальної культури глобалізації [10, 11], а також феномен комп'ютерних віртуальних ігор, які розглядаються як «культурна реальність» та «культурні тексти» [12].

Є. Гашкова у роботі «Культура відсутнього простору: від антроподо кіберцентризму» зазначає, що комп'ютер дає безмежні можливості творити світ силою своєї уяви, і нові можливості комп'ютерної взаємодії-спілкування часом поетизуються та наділяються сакральним ореолом, але все це - лише нові варіанти на тему «Homo ludens», а «віртуальність - це не відсутній простір культури, а культура відсутнього простору» [13, сс. 12-13, 14].

Зацікавленість з боку дослідників викликає і взаємозв'язаність релігії та віртуальності. М. Журба фріксує віртуальну реальність у релігійній сфері як константу, яка, втім, модифікується у залежності від соціокультурних умов [14]. Доцільність застосування віртуалістики у ході вивчення релігійності обґрунтувала О. Бебньова, розглянувши також основні когнітивно-психологічні механізми релігійних уявлень [15]. Р. Іванова зазначає, що взагалі віра (причому навіть позарелігійна) виступає для індивіда як «імпліцитна віртуальна реальність» $[13$, с. 71$]$.

Утім, генералізуючого дослідження, що демонструвало би вплив віртуальності на різні складові (соціальне життя, релігію, освіту, мистецтво тощо) сучасної культури та не існує.

Метою нашої статті $€$ дослідження феномену віртуальної реальності з точки зору його тотального впливу на різні аспекти сучасної культури.

Виклад матеріалу. Почнемо розгляд нашої теми з фіксації того фракту, що віртуальність призвела до фрундаментальних трансформацій у культурі, яка стала не діалогічною, а скоріше - полілогічною, перетворившись також з «культури дефріциту» (обмеженою фрізичною та 
технічною сфрерами) на «культуру надлишку» (з майже нелімітованими обсягами інформації та комунікативним простором) [16, р. 44]. Це не потребує зайвих коментарів, оскільки будь-яка людина, котра стикалася з Інтернетом, розуміє, про що йдеться. Так, на наш пошуковий запит ми отримуємо тисячі (а то й мільйони) відповідей, але справжньою проблемою стає пошук, як нині кажуть, релевантної інформації (не кажучи вже про їі достовірність). На будь-який наш контент, який ми розміщуємо на власній сторінці у соцмережах чи сайті, за секунди можна отримати десятки реакцій. Утім, і полілогічність, і «надлишковість» сучасної культури мають як свої переваги, так і недоліки.

У сучасній культурі виразно спостерігаються явища її віртуалізації, і кіберпростір стає новою площадкою для прояву креативності людини [17]. 3 одного боку, це - чудові безмежні нові можливості, з іншого - це занадто часто панування відвертого невігластва, тому можна легко зрозуміти резони Е. Кіна, який у книзі з промовистою назвою «Культ аматора: як Інтернет вбиває нашу культуру» пише про вимирання традиційних форм культури, на зміну яким йде невігластво, ставлячи риторичне питання: що відбудеться, коли невігластво зустрінеться 3 егоїзмом, а той - з поганим смаком і правилами натовпу? [6, р. 9]. Прогноз автора невтішний.

Особливо сумно ситуація виглядає у науковій і освітній сфрері. Нинішні учні (студенти), так само, як і немале число науковців, не поспішають до бібліотеки, черпаючи інфрормацію з онлайн-простору. Ю. Насєдкіна влучно називає Інтернет «формою енциклопедичного дискурсу» [9, с. 68], але учні частіше за все обмежуються самою лише Вікіпедією, вчителі та викладачі зазвичай шукають більше інформації, але часто їхній критерій лише економічний - наукова продукція 3 відкритим доступом (open-access), а це зовсім не завжди гарантує 
науковість, об’єктивність й тим більше - вагомість тієї чи іншої праці 3 даної проблеми. Ще трагічніше ситуація виглядає, коли вчителі (викладачі) змушені переписувати студентські курсові, дипломні, магістерські й навіть рефрерати. Окрім аморальності подібної поведінки, зрозуміло, що остаточний продукт, як правило, буває дуже низької якості. Складається парадоксальна ситуація - при надзвичайно великих обсягах інформації, що їх нам пропонує Інтернет, у наукових розробках з певної теми можуть фрігурувати одні й ті само цитати, які просто крадуться одне в одного (особливо це стосується іншомовних джерел), причому немає жодної гарантії, що ця цитата адекватна. 3 гірким гумором пригадується ситуація, коли студенти запитували: а де той першотекст, з якого всі списують? ми би краще тоді працювали 3 цим першоджерелом. Не будемо вже згадувати про неетичність ситуації, коли, наприклад, наукові праці авторитетного вченого можуть коментуватися двієчником середніх класів, що видає себе за професіонала. Це ситуація, яка чудово відбита в анекдоті: з настанням 1 вересня на обширах Інтернету різко зменшилася кількість коментарів від експертів у сфрері науки, політики, мистецтва. Проте Інтернет зробив як ніколи легкою та простою реалізацію концепції безперервної освіти для людей будь-якого віку. Та і традиційне навчання отримало нові потужні можливості: платформа Moodle дає можливість завантажувати не лише текстові, але й мультимедійні матеріали 3 курсу; завдяки блогам, сайтам та соцмережам викладач може активніше спілкуватися зі своїми учнями (студентами), у т. ч. нефрормально й має більше важелів для підвищення мотивації до навчання тощо. Це дозволяє С. Павицькій анонсувати нову форму трансляції знань в освіті - «теленавчання» [18].

Якщо говорити про соціальну сфреру культури, то, не беручи до уваги такі трагічні ситуації, як скоєння злочинів (останні сьогодні 
отримали нову платформу завдяки Інтернету - від виманювання грошей до викрадення людей завдяки отриманій, наприклад, у соцмережах інформації), зупинимося на френомені віртуальної комунікації людей на обширах Інтернету. Перебуваючи в онлайнпросторі, люди часто обирають собі нову, віртуальну особистість, яка зазвичай більшою або меншою мірою відрізняється від реальної. Анонімність провокує брехню, але неможливо побудувати нормальні стосунки з іншою людиною через фальшування та маніпуляції. Сама ж віртуальна ідентичність також може призводити до небезпечних, а іноді й трагічних наслідків - віртуальний образ постійно нагадує нам про обмеженість та слабкість реального, викликаючи психози, депресію та навіть роздвоєння особистості [16, р. 47-48]. Водночас онлайн-простір дає нові можливості для приєднання до певної спільноти зі збереженням анонімності, що дозволяє розв'язати якісь свої проблеми (люди, що гуртуються заради того, щоби кинути палити чи схуднути, подолати залежність від нещасного кохання тощо). I тут набагато легше перетнути той психологічний бар'єр, який у реальному житті здавався би нездоланним. «Такі віртуальні співтовариства в мережі компенсують глобальний дефріцит спілкування для осіб, які потребують корекції, соціалізації, інтеграції. Інтернет-спільноти - це ще й нові можливості ідентичності (статусної, сексуальної), включення в які формує почуття приналежності, виводить людину 3 національнокультурної або статусно-неповноцінної ідентичності в простір глобального світу» [19, с. 11].

Неможливо уявити собі нинішнє політичне життя без віртуальних технологій. Інтернет став не лише новою площадкою для реклами політичного бренду, але й подарував реальні можливості формувати суспільну думку та зворотній зв'язок. Кількість т. зв. троллів завжди зростає перед виборами, і політичні партії платять непогані гроші 
людям, котрі готові заробляти на написанні лайливих або образливих коментарів на онлайн-площадках політичних опонентів. Завдяки Інтернету політичні партії також отримали можливість швидко проводити соцопитування в онлайн-режимі, коригуючи свою політику відповідно до отриманих результатів. І навіть протестні акції сьогодні нерідко організовуються, використовуючи нові можливості, що стали доступними завдяки віртуальному простору. Згадаймо, що Революція Гідності відбулася фактично завдяки соцмережам.

Надзвичайно важливу роль грає простір віртуальної реальності в різних релігіях. М. Журба невипадково пише про «гіперактивність віртуальної реальності релігії» [14, с. 80], враховуючи в повному обсязі іiї вплив на життя суспільства. Світ релігії від самого початку $є$ трансцендентальним (лат. transcnedens - такий, що існує за межами реального), і з первісних часів фрормувалися психотехніки, що дозволяли людині вводити себе у стан зміненої свідомості. Причому справа, власне, не в отих психотехніках, а в результатах, отриманих внаслідок таким чи іншим способом досягнутого екстазу. Не можна усе це трактувати як виключно «безумство» і «самозасліплення». Практика свідчить, що плоди такої мандрівки у Трансцендентне виявляються часом життєво потрібними мільйонам людей, становлячи основу їхньої моралі та культури в цілому: доволі пригадати історію Об'явлення Корану Мохаммедові.

Сучасні релігії розширюють обрії духовної самореалізації людини через онлайн-середовище. О. Муха недаремно пише про віртуалізацію релігійної культури, про те, що релігійні практики перекочовують в онлайн-простір [20]. Так, наприклад, численні християнські храми встановили веб-камери, що дає можливість брати участь у богослужінні в онлайн-режимі. Усі більш-менш поширені релігії мають нині свої сайти, блоги, сторінки у соцмережах і навіть онлайн-магазини, 
викладають відеороліки на YouTube. Численні сайти з одкровеннями новонавернених характеризують сучасний іслам, а певні спеціалізовані фроруми вираховують ймовірних ісламістів-радикалів. Серйозно представлений в онлайн просторі буддизм - від наукової та популяризаторської літератури до реклами ашрамів. Англомовні релігієзнавчі студії вже активно вивчають феномен буддизму у вебі - у цій віддавна орієнтований на нірвану світовій релігії тепер фрігурують концепти, покликані розширити фрункцію онлайн-простору, - такі, як «блогісаттва» чи «кіберсангха» [21, 22]. Дуже широко представлене в Інтернеті православ'я, причому, окрім сайтів, що репрезентують той чи інший храм або, скажімо, єпархію, тут можна знайти й більш специфічні ресурси, як, наприклад, український православний сайт знайомств «Надія» або «Спілка православних журналистів». Католицизм, завжди відкритий до новацій, має численні сайти, серед яких назвемо популярне радіо «Марія» та блог Папи Римського. Норвезька лютеранська церква у Хоксунді розмістила на своєму сайті молитву, яку можна прочитати вголос, натиснути «Ок», побачити напис «Вітаємо! Ви отримали спасіння душі!». Український п'ятидесятницький пастор з Маріуполя Геннадій Мохненко, окрім участі в авторській програмі «Другая перспектива», створив власний канал на YouTube. Активно використовують онлайновий простір й інші протестанти, у т. ч., зрозуміло, і з апологетичною метою [23].

Усе це провокує пошук нових понять для відображення специфіки взаємодії релігії та онлайн-технологій. К. Хелланд, наприклад, пропонує такий дихотомічний поділ, як «релігія онлайн» (діяльність реальних релігійних спільнот, що може знаходити своє відображення в онлайн-режимі, але в цілому орієнтована на реальність) та «онлайнрелігія» (орієнтована на віртуальні релігійні дії в Інтернеті) [24]. Формується термін «цифрова релігія», що робить акцент та суміщенні 
(а часто - неможливості розрізнити) онлайн і офрфлайн релігійності завдяки новим медіаформам [25].

Врешті-решт віртуальна реальність серйозно трансформувала copepy мистецтва та літератури. Звичним явищем стали для нас екскурсії по віртуальним музеям, причому такі віртуальні тури дають безліч переваг. Крім очевидних (відвідувати музеї можна, не виходячи 3 дому, в будь-який час, причому безкоштовно), тут $€$ ціла низка прихованих: за допомогою комп'ютера зазвичай можна наблизити зображення й розгледіти його у всіх деталях, увагу не відволікають музейні працівники або інші відвідувачі й часто тут можна побачити навіть ті експонати, які відсутні в експозиціях реального музею (як, наприклад, у Нью-Йоркському музеї сучасного мистецтва, який оцифрував абсолютно всі колекції, і деякі з них доступні лише у віртуальних турах). Утім, кардинально змінилися самі технології у мистецтві. Так, сучасний художник замість фрарб чи олівця може малювати символами ASCII-таблиці, з чого народився ASCII-живопис, який, щоправда, нині вже застарів, і його з гумором називають «наскельним живописом цифрового мистецтва». Виникають навіть нові художні професії: концепт-художник (творець віртуальних дизайнів для об'єктів чи світів) або архітектор віртуальної реальності (креатор нових віртуальних світів). Сучасний скульптор також може творити за допомогою комп'ютерних програм, роздруковуючи результат на 3Dпринтері.

Нових форм набуває література - виникає френомен мережевої літератури, яка має певні переваги у порівнянні 3 традиційною (наявність гіперпосилань, мультимедійного контенту тощо). Це відзначалося вже десятиліття тому М. Хеймом, автором роботи по віртуальній реальності, що сьогодні вважається класикою, «Метафізика віртуальної реальності»: література, переходячи від 
письмової форми до електронної, змінюється, постаючи нелімітованою системою перехресних посилань, і текст може тепер включати гіперпосилання на фільми, музику тощо; так, подібного нового прочитання 3 широкими коментарями заслуговують Джойсівські «Поминки за Фіннеганом» [26, с. 8]. Дійсно, складні літературні твори завдяки системі гіперпосилань (які можуть виступати своєрідними цифровими коментарями та роз'ясненнями) краще розуміються - це може стати однією з реалізацій герменевтичного методу. Крім того, завдяки гіперпосиланням можливою стає реалізація нелінійного сюжету, коли читач сам обирає, в якому напрямку йому рухатися по тексту (класика цього жанру - серія «Choose Your Own Adventure», що вийшла вже понад півстоліття тому).

Усе вищезазначене пояснює, чому нині почали активно говорити про формування віртуальної культури. Щоправда, проблема трактується по-різному. Наприклад, О. Ісакова визначає віртуальну культуру як «вид культури, де віртуальне середовище, побудоване засобами комп'ютерних технологій, як мережеве, так і автономне $є$ способом буття людини» [10, с. 43]. Утім, Д. Усанова фріксує три основних культурологічних потрактування для осмислення віртуальної культури: 1) культура у цілому, як світ людської свідомості, розуміється як віртуальність; 2) віртуальна культура розглядається як інформаційна, аудіовізуальна, медіакультура, Інтернет-культура; 3) віртуальна культура є частиною культури реального світу, але такою, що має специфічні риси в результаті взаємодії з новою реальністю [5, с. 7]. Оскільки термін відносно новий, то зрозуміло, чому він викликає такий різнобій думок. Але проблема семантичного наповнення терміну «віртуальна культура» об'єктивно вимагає окремого розлогого дослідження. 
Отже, можна зробити наступні висновки. 1). Віртуальна реальність не обов'язково $є$ химерою, яка спотворює поведінку та самовизначення людини в світі; частіше вона $є$ суттєвою й результативною кореляцією того, що ми вважаємо за «матеріальну реальність». 2). Онлайн-технології, спрямовані до побудови віртуальної реальності, експансивно трансформують сучасну культуру, даруючи їй певні переваги, але водночас призводячи до нових викликів і проблем. 3) Ці тенденції проявляються у всіх без винятку аспектах культури, зокрема не лише в сфрері розважального, а й у аспектах, пов'язаних 3 найсуттєвішими екзистенціальними проблемами людини.

\section{תimepamypa:}

1. Рогалевич Н. Н. Краткий словарь по философии. Более 1000 слов. - Минск: Харвест, 2007. - 832 с.

2. Балла О. Метафизика в стакане / О. Балла // Знание - сила. 2008. - № 2. - C. 33-41.

3. Корабльова В. Людина як віртуальний конструктор / В. М. Корабльова // Філософрська думка. - 2007. - № 6. - С. 25-33.

4. Бычков В. В., Маньковская Н. Б. Виртуальная реальность в пространстве эстетического опыта / Виктор Васильевич Бычков, Надежда Борисовна Маньковская // Вопросы фрилософрии. - 2006. - № 11. - C. 47-59.

5. Усанова Д. О. Виртуальная культура: концептуализация френомена и репрезентации в современном социокультурном пространстве: Автореф. на соиск. уч. степ. канд. культурологии: 24.00.01 - теория и история культуры / Усанова Дарья Олеговна. Челябинск, 2014. - 24 с.

6. Keen A. The Cult of the Amateur: How Today's Internet Is Killing Our Culture / Andrew Keen. - N.Y.: Doubleday, 2007. - 228 p. 
7. Маньковская Н. Б., Бычков В. В. Современное искусство как френомен техногенной цивилизации / Надежда Борисовна Маньковская, Виктор Васильевич Бычков. - Москва: ВГИК, 2011. - 208 c.

8. Браславский П. И. Технология виртуальной реальности как феномен культуры конца XX-начала XXI веков: Дисс. на соиск. уч. степ. канд. культурол. н.: 24.00.01 - теория и история культуры / Павел Исакович Браславский. - Екатеринбург, 2003. - 163 c.

9. Наседкина Ю. В. Компьютерные виртуальные реальности как феномен современной культуры: Дис. на соиск. уч. степ. канд. культуролог. Н.: 24.00.01 - теория и история культуры / Юлия Валерьевна Наседкина. - СПб., 2005. - 156 с.

10. Ісакова О. І. Віртуальна культура як феномен глобалізації: фрілософрсько-культурологічне осмислення / Олена Іванівна Ісакова // Актуальні проблеми фрілософрії та соціології. - 2017. - Вип. 17. - С. 4143.

11. Муртазина М. Ш. Виртуальная культура как френомен глобализации: фрилософрско-культурологическое осмысление: Дисс. на соиск. уч. степ. канд. филос. н.: 09.00.13 - религиоведение, фрилософрская антропология, ффилософрия культуры / Марина Шамильевна Муртазина. - Чита, 2012. - 172 с.

12. Гутман И. Е. Компьютерные виртуальные игры: культурноантропологические аспекты анализа: Дисс. на соиск. уч. степ. канд. фрилос. н.: 09.00.13 - религиоведение, фрилософрская антропология, фрилософия культуры / Илья Ефимович Гутман. - Санкт-Петербург, 2009. - 193 C.

13. Виртуальное пространство культуры: М-лы науч. конф. 1113 апреля 2000 г. - СПб.: Санкт-Петербургское фрилософрское общество, 2000. - 219 с. 
14. Журба M. А. Віртуальна реальність релііії / M. A. Журба// Філософрія і політологія в контексті сучасної культури. 2014. - Вип. 7. - С. 76-81.

15. Бебнева E. A. Религиозная виртуальная реальность: фрилософрско-религиоведческий анализ: Авторефр. на соиск. уч. степ. канд. фрилос. н.: 09.00.13 - религиоведение, фрилософрская антропология, фрилософия культуры / Елена Александровна Бебнева. - M., 2004. - 26 c.

16. Kasza J. Post Modern Identity: «In Between» Real And Virtual / Joanna Kasza // World Scientific News. - 2017. - № 78. - P. 41-57.

17. Кириллова Н. Б. «Виртуальная реальность» и «виртуализация культуры» как концепты современной культурологии / Наталья Борисовна Кириллова // Обсерватория культуры. - 2017. - №14 (5). C. $524-531$.

18. Павицька С. Ю. Освіта в контексті формування віртуальної культури особистості / С. Ю. Павицька // Гуманітарний вісник Запорізької державної інженерної академії. - 2008. - Вип. 35. - С. 207215.

19. Денисюк Ж. 3. Віртуальність масової культури як поле конструювання уявних ідентичностей / Жанна Захарівна Денисюк // Вісник НАКККIM. - 2016. - № 1. - C. 8-12.

20. Муха О. Я. Виртуализация религиозной культуры, или Как теперь молится юзернейм: наброски к проблеме / О. Я. Муха // Человек и религия: М-лы международ. науч.-практ. конф. (Минск, 14-16 марта 2013 г.). - Минск: Четыре четверти, 2013. - C. 229-233.

21. Buddhism, the Internet, and digital media The pixel in the lotus / Ed. by G. P. Grieve, D. Veidlinger. - N. Y.: Routledge, 2014. - 232 p.

22. Greider B. Academic Buddhology and the Cyber-Sangha: researching and teaching Buddhism on the web // Teaching Buddhism in the West: from 
the wheel to the web / Ed. by V. Nori, R. Hayes, J. Shields. - London, N. Y., 2002. - P. 212-234.

23. Добродум О. Віртуалізація релігії в США / О. Добродум // Релігійна свобода. - 2008. - № 13. - C. 41-46.

24. Helland $C$. Online religion as lived religion: methodological issues in the study of religious participation on the Internet / Christopher Helland // Online - Heidelberg Journal of Religions on the Internet. - 2005. - Vol. 01.1: [Електронний ресурс]. - Режим доступу: http://archiv.ub.uniheidelberg.de/volltextserver/5823/1/Helland3a.pdf.

25. Digital religion: understanding religious practice in New Media Worlds / Ed. H. A. Campbell. - London: Routledge, 2013. - 276 p.

26. Heim M. The Metaphysics of Virtual Reality / Michael Heim. - N. Y.Oxford: Oxford University Press, 1993. - 175 p.

\section{References:}

1. Rogalevich N. N. Kratkiy slovar po filosofii. Bolee 1000 slov. - Minsk: Kharvest, 2007. - 832 s.

2. Balla O. Metafizika v stakane / O. Balla // Znanie - sila. - 2008. - № 2. S. 33-41.

3. Korabl'ova V. Ljudyna jak virtual'nyj konstruktor / V. M. Korabl'ova // Filosofs'ka dumka. - 2007. - № 6. - S. 25-33.

4. Bychkov V. V., Mankovskaya N. B. Virtualnaya realnost v prostranstve esteticheskogo opyta / Viktor Vasilevich Bychkov, Nadezhda Borisovna Mankovskaya // Voprosy filosofii. - 2006. - № 11. - S. 47-59.

5. Usanova D. O. Virtualnaya kultura: kontseptualizatsiya fenomena $i$ reprezentatsii $v$ sovremennom sotsiokulturnom prostranstve: Avtoref. na soisk. uch. step. kand. kulturologii: 24.00.01 - teoriya i istoriya kultury / Usanova Darya Olegovna. - Chelyabinsk, 2014. - 24 s.

6. Keen A. The Cult of the Amateur: How Today's Internet Is Killing Our Culture / Andrew Keen. - N.Y.: Doubleday, 2007. - 228 p. 
7. Mankovskaya N. B., Bychkov V. V. Sovremennoe iskusstvo kak fenomen tekhnogennoy tsivilizatsii / Nadezhda Borisovna Mankovskaya, Viktor Vasilevich Bychkov. - Moskva: VGIK, 2011. - 208 s.

8. Braslavskiy P. I. Tekhnologiya virtualnoy realnosti kak fenomen kultury kontsa KhKh-nachala KhKhl vekov: Diss. na soisk. uch. step. kand. kulturol. n.: 24.00.01 - teoriya i istoriya kultury / Pavel Isakovich Braslavskiy. - Yekaterinburg, 2003. - 163 s.

9. Nasedkina Yu. V. Kompyuternye virtualnye realnosti kak fenomen sovremennoy kultury: Dis. na soisk. uch. step. kand. kulturolog. n.: 24.00.01 - teoriya i istoriya kultury / Yuliya Valerevna Nasedkina. - SPb., 2005. $156 \mathrm{~s}$.

10. Isakova O. I. Virtual'na kul'tura jak fenomen hlobalizaciji: filosofs'kokul'turolohične osmyslennja / Olena Ivanivna Isakova // Aktual'ni problemy filosofiji ta sociolohiji. - 2017. - Vyp. 17. - S. 41-43.

11. Murtazina M. Sh. Virtualnaya kultura kak fenomen globalizatsii: filosofsko-kulturologicheskoe osmyslenie: Diss. na soisk. uch. step. kand. filos. n.: 09.00.13 - religiovedenie, filosofskaya antropologiya, filosofiya kultury / Marina Shamilevna Murtazina. - Chita, 2012. - 172 s.

12. Gutman I. Ye. Kompyuternye virtualnye igry: kulturnoantropologicheskie aspekty analiza: Diss. na soisk. uch. step. kand. filos. n.: 09.00.13 - religiovedenie, filosofskaya antropologiya, filosofiya kultury / Ilya Yefimovich Gutman. - Sankt-Peterburg, 2009. - 193 s.

13. Virtualnoe prostranstvo kultury: M-ly nauch. konf. 11-13 aprelya $2000 \mathrm{~g}$. - SPb.: Sankt-Peterburgskoe filosofskoe obshchestvo, 2000. - 219 s.

14. Žurba M. A. Virtual'na real'nist' relihiji / M. A. Žurba // Filosofija $i$ politolohija v konteksti sučasnoji kul'tury. - 2014. - Vyp. 7. - S. 76-81.

15. Bebneva Ye. A. Religioznaya virtualnaya realnost: filosofskoreligiovedcheskiy analiz: Avtoref. na soisk. uch. step. kand. filos. n.: 
09.00.13 - religiovedenie, filosofskaya antropologiya, filosofiya kultury / Yelena Aleksandrovna Bebneva. - M., 2004. - 26 s.

16. Kasza J. Post Modern Identity: «In Between» Real And Virtual / Joanna Kasza // World Scientific News. - 2017. - № 78. - P. 41-57.

17. Kirillova N. B. "Virtualnaya realnost» $i$ "virtualizatsiya kultury» kak kontsepty sovremennoy kulturologii / Natalya Borisovna Kirillova // Observatoriya kultury. - 2017. - №14 (5). - S. 524-531.

18. Pavyc'ka S. Ju. Osvita $v$ konteksti formuvannja virtual'noji kul'tury osobystosti / S. Ju. Pavyc'ka // Humanitarnyj visnyk Zaporiz'koji deržavnoji inženernoji akademiji. - 2008. - Vyp. 35. - S. 207-215.

19. Denysjuk Ž. Z. Virtual'nist' masovoji kul'tury jak pole konstrujuvannja ujavnyx identyčnostej / Žanna Zaxarivna Denysjuk // Visnyk NAKKKIM. 2016. - № 1. - S. 8-12.

20. Mukha O. Ya. Virtualizatsiya religioznoy kultury, ili Kak teper molitsya yuzerneym: nabroski k probleme / O. Ya. Mukha // Chelovek i religiya: M-ly mezhdunarod. nauch.-prakt. konf. (Minsk, 14-16 marta 2013 g.). - Minsk: Chetyre chetverti, 2013. - S. 229-233.

21. Buddhism, the Internet, and digital media The pixel in the lotus / Ed. by G. P. Grieve, D. Veidlinger. - N.Y.: Routledge, 2014. - 232 p.

22. Greider B. Academic Buddhology and the Cyber-Sangha: researching and teaching Buddhism on the web // Teaching Buddhism in the West: from the wheel to the web / Ed. by V. Nori, R. Hayes, J. Shields. - London, N.Y., 2002. - P. 212-234.

23. Dobrodum O. Virtualizacija relihiji v SŠA / O. Dobrodum // Relihijna svoboda. - 2008. - № 13. - S. 41-46.

24. Helland C. Online religion as lived religion: methodological issues in the study of religious participation on the Internet / Christopher Helland // Online - Heidelberg Journal of Religions on the Internet. - 2005. - Vol. 01.1: 
[Електронний ресурс]. - Режим доступу: http://archiv.ub.uniheidelberg.de/volltextserver/5823/1/Helland3a.pdf.

25. Digital religion: understanding religious practice in New Media Worlds / Ed. H. A. Campbell. - London: Routledge, 2013. - 276 p.

26. Heim M. The Metaphysics of Virtual Reality / Michael Heim. - N. Y.Oxford: Oxford University Press, 1993. - $175 p$. 